\title{
Chapter 2 \\ The Goal of the Universal Design \\ for Learning: Development of All to Expert \\ Learners
}

\author{
Julita Navaitienė (D) and Eglẻ Stasiūnaitienė (D)
}

\begin{abstract}
Over the past 10 years, every learner's ability to achieve the highest level of learning success has become quite an important topic. The Universal Design for Learning (UDL) sets a goal to allow all learners to achieve their optimal learning experience that matches inclusive education. Learners who can assess their own learning needs set their personal learning goals, and monitor their progress are termed the expert learners (McDowell. Developing expert learners: a roadmap for growing confident and competent students. Corwin, 2019). This chapter focuses on theoretical backgrounds for expert learners' paradigm. It starts from fundamental constructivist theories and moves towards the theory of self-regulation and cognitive neuroscience approach. It concentrates on the theory of self-determination, which, in our opinion, validates in the best way the nature of the expert learners' development. Implementation of the Universal Design for Learning allows all learners to access, participate in, and progress in the general-education curriculum. This chapter presents the specific profile of the expert learners covering their main characteristics and qualities and revealing the essence of the UDL framework. Educators could use the profile as the educational guidelines conductive to understand how the process of becoming the expert learner proceeds.
\end{abstract}

Keywords Expert learner · Universal design for learning $\cdot$ Self-determination theory $\cdot$ Profile of expert learner

\subsection{Why Expert Learners?}

Classrooms are remarkably diverse now globally, and that fact enriches today's school as well. Each learner is unique and needs various individually appropriate learning methods according to their abilities, intelligence, and learning styles. Every

J. Navaitienè $(\bowtie) \cdot$ E. Stasiūnaitienè

Educational Academy, Vytautas Magnus University, Kaunas, Lithuania

e-mail: julita.navaitiene@vdu.lt; egle.stasiunaitiene@vdu.lt 
learner can achieve their own highest level of learning potential. Setting realistic, achievable, but challenging goals, actively engaging with the learning material, taking responsibility for learning, and controlling the learning process, the learners commit to growing. The concept of the expert learner is most closely associated with learning success and the development of a growth mindset. It is defined in different ways by various researchers and practitioners, but the desire to learn and to know how to learn best dominates most definitions. Schwartz and Manning (2018a, b) argue that expert learners are notable for their planning, resourcefulness, diligence, and confidence. They control their learning, and therefore they study differently.

However, most of the students are learning according to the general education curriculum (Darling-Hammond et al., 2020). Understanding the curriculum as a sequence of learning opportunities provided to students clarifies that the learning environment should be designed so that everyone can grow knowing and using his or her strengths. In this way, people could perceive students with different learner profiles as unique learners with equitable developmental opportunities (Bali \& Caines, 2018).

The Education 2030 (UNESCO, 2015) proposed a new vision for education to ensure inclusive and equitable quality education for all. UNESCO's head of Education, Stefania Giannini (2021), shares imperatives for an education recovery package due to the COVID-19 pandemic, and the first imperative is to reopen schools safely and inclusively. Inclusive education is the core of transforming educational systems, enhancing learning opportunities for all learners, supporting the personalization of education, and changing the traditional one-size-fits-all approach to learning. Opertti et al. (2014) delineate an inclusive curriculum as developing shared goals, strategies, and practices and responding to the uniqueness of each learner. The Council of the European Union's recommendation on shared values and inclusive education and the European dimension of teaching (2018) calls for ensuring equal adequate access to quality inclusive education for all learners (e.g. migrants, disabled, talented, or poor) (European Commission 2018). The European Agency for Special Needs and Inclusive Education (2019) stresses the changing role of specialists in providing inclusive education by supporting the rights of all learners.

The Global Education Monitoring report "Inclusion in education: All means All" (2020) proposes the universal design for learners as an effective strategy for the inclusion of all learners.

Inclusive education environments are barrier-free: applying the universal design for learning strategy helps to remove physical, sensory, and cognitive barriers to learning and ensure accessibility of inclusive education for all learners. There is an increased focused attention to academic achievement as the most crucial goal of education in many countries. Inclusive education aims to provide all students with the most appropriate learning environments to achieve their best potential (Hornby, 2015).

There is a framework that provides all the students with equal opportunities to learn. Universal Design for Learning (UDL) describes a practice and sciencebased framework to support education, give challenges, and expand opportunities 
for all learners. It is a way to involve every student in the learning experience, promote fully inclusive learning, and facilitate success for all learners with different abilities.

The use of the UDL enabled the teachers to teach all learners and reduce the learning barriers that arise during the general education curriculum uptake (Rao et al., 2016). Creating the path of successful inclusion for students with different needs, the UDL helps provide an engaging, accessible, and expressive learning environment (Evmenova, 2018). Rose et al. (2018) emphasize that the UDL focuses on weaknesses and barriers in designing the learning context itself, not on the learners. One of the primary goals of the UDL framework is to improve and optimize learning for all students. Griful-Freixenet et al. (2020) explored the inter-relationship between UDL and differentiated instruction as two pedagogical models and found that both declare the variability in any group of students. Therefore, the teachers should adjust their teaching according to diversity in the field of inclusive education. Cook and Rao (2018) highlighted how secondary teachers could adapt effective practices of UDL for learners with learning disabilities. According to Rose and Meyer (2002), UDL guides students to be the best learners they could be. The recommended process should help students to become more expert learners. It should not take the form of filling students with the knowledge, but of students taking care of their learning.

The concept of expert learners is closely associated with the universal design for learning. Students can become expert learners as they develop and make themselves more knowledgeable, skilful, and motivated (Meyer \& Rose, 2000; Meyer et al., 2014). The students who want to learn and know how to learn are successful learners in most cases. UDL implementation aims to develop the learners who know their own learning needs and can meet them by regulating their behavior, thinking, and emotions. Rose and Meyer (2002) emphasized that UDL could provide equal access to education and guide students to be the best learners they can be.

Active educational inclusion involves the recognition that we can support all learners according to their differences. UDL principles for learning help create a supportive environment within which the educational goals will be student-centred and directed to the mastery of learning. Black et al. (2015) note that UDL aims to be inclusive for all learners and helps to reduce barriers, especially for those with disabilities. Dalton et al. (2019) provided examples of applying the UDL principles for learning from South African and US institutions of higher learning. They approved the use of UDL to strengthen the successful inclusion of learners with differing needs. The UDL model of inclusion treats disability as only one of many dimensions of learners' differences. Bray and McClaskey (2016) explain how personalizing learning presents the UDL framework as a very flexible approach to individual differences and needs of all learners. These authors described the expert learners as independent, self-directed, and self-motivated. Quirke and McCarthy (2020) recognize that UDL ensures the inclusive learning environment of the greatest extent and adapts the best pedagogical approaches.

Applying the UDL framework in the classroom would not be efficient enough if there is no challenge for students to become purposeful, motivated, resourceful, 
knowledgeable, strategic, and goal-directed; in other words, if we do not nurture expert students in the classroom.

\subsection{Theoretical Basis for Expert Learners' Development}

Inclusive education focuses not only on "access" to learning but also on the "participation" and "progress" of learners (Ainscow, 2020; Ramberg \& Watkins, 2020). To understand the implementation possibilities of inclusive education through the UDL framework, we should analyze the theories and approaches that could support expert learners' development using the classical and the newest ones.

Constructivist Learning Theories uphold the proposition that learning results from mental construction when new information fits together with what is already known. UDL proposes that students become active learners and extend their understanding by connecting further and current information. The construction of knowledge requires learners' activities; therefore, it is a continually dynamic process in which students transform their cognitive structures. The task of the teacher is to engage the learners to be active participants in their learning process. Findings from the neurosciences that reveal a vibrant and flexible interaction between the environment and the learning brain strengthen constructivist learning theories and the UDL framework. The principles of UDL refer to the recognition, strategic, and affective neural networks to reflect the specializations in the learning process. Knowledge and skills are traditionally the mainstays of learning. Expert learners can discover new and open-ended connections of novel information. Expert learners see learning as purposeful and meaningful when they can operate with knowledge received. Since expert learners actively create their knowledge, it is customary for them to ask questions and explore.

Piaget's cognitive theory (Piaget, 1973) is one of the most influential constructivist theories in education. It relates to how knowledge is constructed and constantly reconstructed through personal experience. This theory declared cognitive development as a process guided by biological maturation and interaction with the environment. Therefore, knowledge (as the cognitive structures) varies from learner to learner because of their personal experiences and level of development. Although scientists have questioned Piaget's cognitive theory, it could be useful for the teachers to understand how to facilitate the active creation of knowledge by expert learners. Different ways of understanding the world characterize the learners.

Bruner's constructivist theory (Bruner, 1977) presents learners as comparing new ideas to old ones and searching for similarities and differences. In turn, the teacher should translate learning information according to the learners' state of understanding. Representation and categorization are keys to learning. The learners choose and transform data and make decisions based on their cognitive structures. This theory views the role of teachers in student learning as very important because they can teach some aspects of any learning content to any learner. The theory 
reveals three modes of representation used in the learning process: enactive, iconic, and symbolic. To demonstrate knowledge through appropriate motor activity, use enactive representation. Iconic representation includes the use of images, signifiers, and structures to express understanding. Symbolic representation-the most common mode-comprises the use of language and symbols. The teachers can learn from this theory about the importance and ways of representation when teaching expert learners. The theory also exposes the heuristic nature of learning. In this theory, mastery of fundamental ideas is related to understanding general principles and solving problems.

Vygotsky's social constructivist theory (Vygotsky, 1978) reveals that learners ought to be engaged in the learning process to construct knowledge and learn from one another. Learning of cooperative learning groups is based on the benefits of social interaction. Relying on group work and peer-peer interaction, the construction of knowledge becomes more efficient. The theory submits social interaction as the practical framework for learning. Recognition of the relationship between the learning process and social activities led to the suggestion that learning occurs with the teacher's support and classmates. The learners do not hesitate to seek help from the teacher or other learners when they need it. There are three essential principles of learning according to the theory. The first principle emphasizes the critical role of social interaction in learning. The second one is associated with the potential of the learner's cognitive development. This theory accentuates that each learner has an individual extent of learning potential and describes it as the zone of proximal development. The third principle points to the importance of a supportive and conducive learning environment. Vygotsky's theory analyzes the role of culture in developing higher mental functions such as attention, memory, thinking, and language. Learning is the internalization of social processes and the translation of social functions into higher cognitive functions. With this, the teachers provide direct learning experiences to the learners. The theory may be helpful for teachers who want to understand their role in the learning of expert learners clearly and seeks to facilitate their learning.

Social Cognitive Learning Theory (Bandura, 1991) espouses reciprocal determinism and describes it as the interaction between behavior, personality, and the environment. One of the essential concepts in this theory is anticipation that orients people's actions, motivates them, and helps people choose their direction of activity. The approach emphasizes the importance and significance of self-regulation through self-reflection and self-evaluation. The term self-efficacy is unique to this theory and refers to the learners' confidence in their ability to learn successfully. Selfefficacy is the foundation of learners' potency to learn. Learners believing in learning success strive to reach their learning goals, perform effectively, and persist in the face of difficulties.

It should be noted that some learning barriers can limit learners' self-efficacy, which is an important message for inclusive education practitioners. It is worth noting that the core component of learning is self-regulation, and the daily learning activities of expert learners include this component in most cases. It usually 
means reflecting on one's understanding. The students are motivated to actively participate in the accommodation and assimilation of new information through relevant activities and then reflect on their experiences. Bandura (1991) proved that students could control their behavior and referred to it as a process of selfregulation. Self-regulation is associated with identifying a set of goals and with the endeavours to attain the goals. Therefore, the teacher who wants to educate a goal-oriented expert learner should be interested in the recommendations of this theory.

Constructivist learning theories reaffirm that students' learning becomes more successful when they actively construct knowledge and understanding using their own experiences. By applying different learning strategies, students in the constructivist classrooms have the real opportunity to become expert learners.

\section{Cognitive Neuroscience Approach}

Discoveries of cognitive neuroscience about learning brain: neuroplasticity and variability (Fandakova \& Hartley, 2020), curiosity (Gruber et al., 2019), memory (Quent et al., 2021), goal-directed behavior (Huang et al., 2020), importance of prior knowledge (Alonso et al., 2020) help teachers to design learning environments that take advantage of these brain characteristics.

Contemporary neuroscience research suggests learning results from different large-scale network activity in the brain (Cantor et al., 2018; Quent et al., 2021; Mattar \& Bassett 2020). These networks cooperate in the learner's brain for completing specific cognitive functions (Siew et al., 2019). Cognitive neuroscience offers a theoretical framework for understanding brain functioning as a system covered by neurons' structural and functional networks (Petersen \& Sporns, 2015). Hartwigsen (2018) emphasizes a new perspective on the compensatory flexibility of these brain networks.

The cognitive neuroscience approach to learning brain includes the standard action of three sets of neural networks: (1) recognition network that helps the learner to recognize the patterns, collect information, and put it into meaningful categories, (2) strategic network that assists a learner to plan and generate the patterns and perform tasks, and (3) effective network that determines which patterns are most important for a learner and manage motivation and engagement (Rose \& Strangman, 2007). Cognitive neuroscience studies of the brain have confirmed that these three main networks are active during learning (Siew, 2020; Wardle \& Baker, 2020; Allegra et al., 2020; Markett et al., 2018).

The use of these networks in inclusive teaching and learning is applicable and makes the development of expert learners more effective through meeting learners' needs and considering individual learners' differences. Expert learners are managing specific networks of knowledge in their brains: "knowing what", "knowing how", and "knowing why". Therefore, expert learners are prepared for learning, know how to learn, and want to learn. An expansion of the "knowing what" network contributes to the development of resourceful and knowledgeable learners, a strengthening of the "knowing how" network develops strategic and goal-directed learners, and activation of the "knowing why" network develops purposeful and motivated learners. 
Siew (2020) points to the fundamental goal of education as structural and functional changes within the knowledge networks of learners. The learners assimilate the meaningful knowledge when they progress from being the novices to the experts. Expertise is associated with developing complex and hierarchical cognitive structures in the brain (Bilalić \& Campitelli, 2018).

Persky and Robinson (2017) present several characteristics of experts. For example, they argue that experts know more, and their knowledge is better organized and integrated into the existing knowledge system. They also have effective strategies for using knowledge, have strong motivations, and are sufficiently self-regulated because their knowledge is well-organized. Consequently, making inferences, concluding, and finding solutions do not seem impossible to them.

Transforming learners into expert learners is doable if the three brain networks (recognition, strategic, and affective) are targeted by the UDL framework.

Self-Regulated Learning Theory is one of the new but widely accepted learning theories within education. It emphasizes the students' achievements in learning by metacognition, self-control, motivation to learn, autonomy, planning, monitoring, and evaluating (Zimmerman, 1990, 2000, 2002, 2015; Perry \& Rahim, 2011; Panadero, 2017; Zeidner, 2019). Self-regulated learning is defined as a self-directed learning goal process through monitoring, controlling, and reflecting on one's learning (Zimmerman \& Schunk, 2008; Zimmerman, 2015). Walker and Russell (2019) considered self-regulation as one of the executive functioning skills.

According to Panadero (2017), self-regulated learning involves six models and many different factors that motivate learning. The Metacognitive and Affective Model of Self-Regulated Learning or MASRL (Efklides, 2011, 2019) presents selfregulated learning as a complex and dynamic process that includes the learning task, abilities, knowledge and skills, motivation, feelings, and judgments. Despite being young, a significant number of scientific articles have already analyzed this model. Pintrich (2000) delineates self-regulated learning as an active process and presents the model of self-regulated learning. This model includes four phases: forethought, planning, and activation; monitoring; control; and reaction and reflection. Each stage has four areas for self-regulation: cognition, motivation, behavior, and context. Goal orientations are the fundamental construct in this model and are why learners perform the learning tasks.

It is important to note that educators could teach their students to become selfregulated learners (Schunk \& Zimmerman, 1997, 1998). Zimmerman (1986, 2000) has developed three self-regulated learners' development models: the Triadic Analysis model, Three Phase Cyclic model, and Multi-Level model. The fourth and latest model, called the Social-Cognitive Multi-Level model of SelfRegulation Development, consists of the four stages in which learners acquire self-regulatory competency (Zimmerman \& Kitsantas, 2005). These stages are observation, emulation, self-control, and self-regulation. In the observation stage, learners pay attention to the expert's (e.g. teacher's) example of activity. In the emulation stage, learners perform, keeping in mind the model seen, but seldom copy it precisely because of lack of skills. Teachers can facilitate emulation until 
students achieve a suitable level of mastery. The self-control stage begins when learners can practice in the absence of the example. Practice should be reflective and structured, helping to reach some automaticity. The amount of learners' selfreinforcement could determine their success in this stage. In the self-regulation stage, learners perform in new or changing conditions, monitor and evaluate the results, and plan their future performance. Learners do not have to go through all four stages to develop self-regulation; however, being present at these stages is desirable.

Self-regulated learners could be described as active participants in their learning process-emotionally, motivationally, and cognitively (Zimmerman, 2001, 2002). They can take up and channel their learning activity to achieve the personal learning goals they set. They can set achievable, realistic learning goals, seek, acquire, organize, and transform information, control and direct their mental processes, and implement the most appropriate cognitive strategies and actions to achieve learning goals. Self-regulated learners are interested, self-motivated, organized, persistent, diligent, and analytical. They nourish high self-efficacy and positive emotions (e.g. enthusiasm) towards their learning goals, knowing how to create a suitable learning environment. They fearlessly seek support and help from their teachers and classmates when they need it and actively participate in regulating academic tasks, performance evaluation, and workgroup organization. Self-regulated learners can avoid or overcome external or internal distractions during the learning process.

Self-regulated learners become masters of their learning processes, transforming their intellectual abilities into task-related skills (Zimmerman, 2015). As the driver of the development of the expert learner, the teacher could provide the support and scaffolding when the learner's self-regulatory practices develop.

By generalizing and summarizing many approaches to self-regulated learning, we find that there are three significant phases of self-regulation learning: (1) planning one's learning (analysing the learning task, setting learning goals, and planning learning strategies); (2) monitoring progress of plan implementation (implementing the plan from phase one and monitoring the progress of implementation); (3) evaluating the outcome of the plan application (determining how well planned learning strategies worked). Reflection (including self-questioning, which facilitates the reflective process) goes on throughout all three phases.

Kitsantas et al. (2000) revealed the differences between experts and novices in their self-regulation. Experts know when and how to apply the knowledge they have learned, whereas beginners learn reactively without planning or reflection. It is essential that experts like and can set personal goals for themselves.

Steiner (2016) investigated the differences between lower and higher achieving learners and discovered that self-regulated learning strategies, such as managing study time, handling goals, and metacognitive reflection, increased learners' test grades and self-confidence.

Self-regulated learning unlocked a new perspective on developing expert learners who became successful because of control of the learning environment. The relationship between self-regulation and expert learning manifests itself in how the students master and manage their education. 
The Self-Determination Theory of Deci and Ryan $(1985,2012)$ presented a selfdetermined motivation theory of intrinsic motivation. It later grew to selfdetermination theory and became one of the most widely applied, functionally focused, and empirically supported views.

Self-determination as a psychological construct indicates self-caused, volitional actions (Wehmeyer et al., 2017). The scientific literature has offered several definitions of self-determination. Still, after analysing for standard features, it turned out that self-determination is a combination of knowledge, skills, values, and attitudes that enable a person to perform goal-directed, self-regulated, and autonomous activity. Hui and Tsang (2012) reviewed self-determination as a psychological and positive youth development construct. They defined it as the competence of young people in engaging in voluntary behavior and their autonomy in making choices and decisions. Legault and Inzlicht (2013) examined how independence improves performance by enhancing neuro affective responsiveness and highlighted the importance of autonomous motivation.

Self-determination theory provides a framework for understanding the factors that promote the learner's learning motivation and efficient psychological functioning. It is a basis for learners' self-motivation and personal growth. SDT emphasizes the importance of the three most important, innate, and universal human needs: competence (one's need to have achievements, knowledge, skills, and mastery over different vital tasks), relatedness (one's need to belong and connect with others), and autonomy (one's need to feel that one is in control of his or her behavior) (Ryan \& Deci, 2000, 2016, 2017).

SDT has much breadth and depth because it consists of six mini-theories (Ryan $\&$ Deci, 2019): (1) Cognitive evaluation theory, explaining effects of rewards, feedback, external events, and interpersonal and intrapersonal processes on intrinsic motivation; (2) organismic integration theory, clarifying internalization and differentiation of extrinsic motivation; (3) causality orientation theory, authorizing individual differences in motivational orientations; (4) basic physiological needs theory, telling about satisfaction and frustration of autonomy, competence, and relatedness concerning psychological wellness and full functioning; (5) goal contents theory, revealing aspirations, life goals, and their varied consequences; and (6) relationships motivation theory, expounding the self in close relationships.

Wehmeyer (1999) suggested understanding self-determination as an educational construct. He has proposed that one can develop self-determination through learning.

The application of self-determination theory to educational settings has proven productive (Reeve, 2002; Denney \& Daviso, 2012; Raley et al., 2018; Hagiwara et al., 2020; Ryan \& Deci, 2020). SDT could explain why some learners are engaged and motivated in their learning and why learners' autonomy facilitates their learning and develops their competencies. Many studies have identified a strong correlation between academic achievement and self-determination of learners with and without disabilities and focused teachers' attention on the self-determination skills teaching (Mithaug et al., 2003; Gaumer Erickson et al., 2015; Shogren et al., 2015; Shogren 
\& Ward, 2018; Manganelli et al., 2019; Raley et al., 2020). SDT appreciates the learners as mature enough to know what is worth doing, capable of acting in their interests, sufficiently knowing why they need to learn, and using what they learned. They do this because they are naturally curious and want to explore and understand. They can organize and manage their learning (Wehmeyer \& Zhao, 2020).

Field and Hoffman (1994) developed a five-step model for self-determination, defining self-determination as the ability to identify and achieve goals based on a foundation of knowing and valuing oneself. The model has five major components: (1) self-knowledge; (2) self-evaluation; (3) planning; (4) acting; and (5) experiencing outcomes and learning. The first two components describe self-awareness, the following two components identify planning, and learning skills reasoned on selfawareness. The final element of self-determination includes evaluation of one's actions. This model was applied to the development of self-determination of learners and served as the basis for the steps to self-determination curriculum formation (Hoffman \& Field, 2005). Self-determination developmental programs validated by this model have helped learners participate more actively in their education. They were able to reflect on what is important to them, set relevant goals and achieving those goals, and answering their basic psychological needs of autonomy, relatedness, and competence.

The concept of the three basic psychological needs provides a sound basis for predicting whether the learning environment will support optimal learning. Learners experience competence when they are challenged by the tasks and given constructive feedback from the teachers. Learners meet their need for relatedness when communicating and collaborating with teachers and classmates, who are listening and responding to them. Learners satisfy the need for autonomy when they feel supported by teachers and classmates to take the initiative and perform. Learners are engaged in their learning and motivated to learn when the educational environment is created and friendly to satisfy all three needs.

Wehmeyer (1999) established a functional model of self-determination with four fundamental components: (1) behavioral autonomy; (2) self-regulated behavior; (3) psychological empowerment; (4) self-realization. They reveal abilities (behavioral autonomy and self-regulation) and attitudes (psychological empowerment and selfrealization) that must be developed if a person wants to be self-determined. The self-determined learning model of instruction was developed on components of this model (Wehmeyer et al., 2000). It was a model for teachers seeking to engage the learners in self-determined learning and enable them to self-regulate and self-direct during the learning process (Shogren et al., 2017). A model could be used as a pattern to create curriculums and to prepare instructional materials. It has three phases: (1) the first phase helps to determine what learners want to learn and what instructional goals to set; (2) the second phase helps to know what is needed to learn and possible barriers to learning; (3) the third phase contributes to actions for goal achievement and removal of barriers.

The development of self-determination training models continues to this day. Chambless et al. (2019) proposed the "achieving success by promoting readiness for education and employment" (ASPIRE) model for teaching self-determination to 
youth with disabilities. This model defined 13 central elements of self-determination development: (1) choice-making; (2) decision-making; (3) problem-solving; (4) goal-setting and attainment; (5) independence with safety and risk-taking; (6) selfobservation, self-evaluation, and self-reinforcement; (7) self-instruction; (8) selfadvocacy and leadership; (9) positive efficacy and expectations; (10) self-knowledge and self-awareness; (11) understanding of one's disability and one's ability to talk about his or her disability; (12) disclosure of disability and ability to ask for accommodations; (13) receive and exploit effective assistive technology. Most of these components overlap with those provided by Wehmeyer et al. (2013) and Wehmeyer (2019) for the education of all learners.

Identifying the characteristics of self-determined learners (e.g. skills, abilities, attitudes, and beliefs) enables educators to develop self-determination in their students and clearly understand what qualities to develop.

According to Wehmeyer (1996) and Wehmeyer et al. (2007), self-determined learners have four essential characteristics:

1. Autonomous behavior according to their learning interests, needs, preferences, and abilities

2. Self-regulated behavior, including self-monitoring, self-instruction, selfevaluation, and self-reinforcement, learning goal setting and attainment, and problem-solving

3. Psychological self-empowerment through the internal locus of control (the belief that they have control over their learning), self-efficacy (the idea that they have sufficient skills to achieve desired learning goals), and positive expectations (the belief that satisfactory learning outcomes will be achieved when choosing to apply those skills)

4. Self-realization using self-knowledge (knowledge of their strengths and limitations) and self-understanding (ability to understand their actions, thoughts, and emotions)

Learners who possess these four functional characteristics are self-determined. Each element is necessary but not sufficient. The learning environment or, for example, the age of learners may impact the level of the essential characteristic. Autonomous learners can act relatively independently from the influences of the environment or more dependently on it. Bigby and Douglas (2020) suggested schematic representation of the framework, which conceptualized support for decisionmaking and spotlighted the needs of learners with cognitive disabilities to be supported sometimes. Self-regulating learners can cope with how their environment influences their plans and revise their plans according to the influences of their environment. Self-empowered learners can feel self-effective and exhibit internal locus of control or feel insufficiently competent and often perceive external control. Selfrealizing learners can use comprehensive self-knowledge or focus on superficial self-knowledge because self-understanding forms through self-reflection.

Since self-determination enables the learners to engage in goal-directed, selfregulated, and autonomous learning, knowing and understanding these four essential characteristics can help teachers find the most effective strategies to develop them. 
The four characteristics of a self-determined learner discussed above are associated with several qualities. Although there is no exhaustive taxonomy of these qualities, some of the markers are most common (Wehmeyer et al., 2007; du Toit-Brits \& van Zyl, 2017; Raley et al., 2020; Shogren, 2020) and can be the guidelines for teachers developing self-determined learners. Below is a brief description of some of these qualities.

Choice-making skills are one of the qualities of self-determined learners who take the opportunities to express their wishes and preferences, making their own constructive choices. They can select an item or activity from a variety of options at a particular moment in learning. That way, they become relatively independent learners. They make choices about what kind of task to carry out, what activity to pursue, how to spend leisure time, and so on. Stating preferences and making choices, learners become more engaged and interested in learning. Self-determined learners can explain their priorities to teachers or classmates and choose without coercion. When learners express their choices based on their preferences, they can make independent decisions.

Decision-making skills make self-determined learners quickly and responsibly identify the situation, consider potential solutions or actions, set down the advantages and disadvantages of each option, and make the decision. They can combine logic and intuition to think the right way, consider teachers' and classmates' views, and know their priorities and values. They are open-minded, willing to change, and be flexible. Self-determined learners are realistic: they understand what can or cannot be done in such a situation. Decision-making and problem-solving are closely related because many decision-making skills are helpful to problem-solving.

Self-determined learners can identify the problem, revise multiple alternative possible solutions, identify possible consequences, select the most appropriate solution, implement this solution, and verify its effectiveness. If the issue remains unsolved, they try to resolve it by involving someone else in the problem-solving process, looking for help, applying another coping strategy, using critical thinking, and so on. They usually have positive expectations for problem-solving and persist against emotional stress. By solving problems, self-determined learners reduce or eliminate the discrepancies between what they expect and what they receive from learning in reality.

Goal setting and attainment skills enable learners to determine a goal, develop a plan to achieve that goal, and monitor the goal achievement process. Selfdetermined learners can define what they want or need to learn, refine their goals to be clear, break the goals into objectives, and list the options and possible consequences of the options. They can also choose the best option, act on it, monitor and evaluate their progress, and decide if they have met the goals. If not, they adjust or change it. If yes, they reinforce themselves. When setting learning goals, they are not afraid of taking risks, and when attaining the goals, they develop support networks. Setting and achieving goals regulate self-determined learners' efforts and persistence.

Self-management skills allow the learners to control their thoughts, feelings, and actions. Self-determined learners can explain the purpose of self-management. To 
manage themselves, they monitor their behavior, attend to when and why they use such behavior, assess observed behavior, and continue or change it. They understand their strengths, seek opportunities to maximize their abilities, believe in themselves, plan their time, know what is most vital for them, and are accountable and feel responsible for their behavior.

Self-advocacy and leadership skills help self-determined learners to protect and make themselves more assertive. Without some degree of advocating for themselves, the learners would not attain their personal goals. Self-determined learners can be sufficiently assertive in gaining knowledge, defend their opinions and/or their rights, seek and maintain reinforcement, express an unpopular or different idea, persist in actions to achieve the desired goal, and employ negotiation and compromise. They view themselves as leaders, inspire classmates to learn and influence their opinions, resolve conflicts, facilitate teamwork and participation, critique ideas or proposals in a constructive manner, and so on. Selfdetermined learners can express opinions and speak up for themselves and their classmates.

High self-efficacy and positive outcome expectations make self-determined learners believe in performing at a designated level of performance. Self-determined learners are convinced that they will solve problems and accomplish goals if they invest the necessary efforts. They obtain essential outcomes, successfully overcome challenges, focus on progress, strive for excellence, not for perfection, are selfconfident, not fearful of failure or mistakes because of viewing mistakes as opportunities for improvement. Those with high self-efficacy, in most cases, have an internal locus of control.

Internal locus of control is specific for self-determined learners and means perception of events and outcomes. In education, the internal locus of control refers to how learners perceive the causes of their academic success or failure. Selfdetermined learners attribute success to their endeavours and abilities, believe in self-control of their life events, consider themselves responsible for success and failure, and view the learning process as controllable and not difficult. They believe in their ability to grow with effort and to correct their performance by themselves. They quickly recognize their mistakes, difficulties, and setbacks. They follow an optimistic attitude, thrive in more unstructured learning environments, take responsibility for their actions and decisions, and provide more assistance, help, and support.

The self-awareness of self-determined learners brings clarity to their internal state. Self-determined learners can use self-insight and self-reflection to explore self-perception, self-knowing, and self-understanding. They foster their emotional intelligence and recognize how teachers and classmates see them. They have a deep understanding of their values, motives, and psychological needs, are realistic and self-critical, open to feedback, easily communicate their thoughts and emotions, understand and accept individual differences, and handle frustration and stress well. Self-determined learners become attentive self-observers. They make value judgments and feel the freedom to become self-accepting. 
These qualities define a self-determined learner, but each is not necessary because of the developmental nature of self-determination. Self-determination emerges not only during school years when learners cultivate self-determination skills. The development of self-determination continues throughout all life span. Learners can experience different levels of self-determination skills during the maturation process.

Promoting self-determination, teachers may focus their instructional efforts on the qualities of self-determined learners. Teachers ought to understand the importance of self-determination as an essential educational outcome for all learners.

Self-determined learners are driven by intrinsic learning motivation and easy to accept learning challenges, which helps them be active and participate. Active participation in one's learning is highly effective in the context of twenty-first-century education (Triling, 2015; Freeman et al., 2014). Learners play an essential role in their learning process. They are encouraged to actively receive information from the teacher and build knowledge and understanding by engaging in the learning process. Active learning and self-determined learning agree with each other in learners' engagement in small or large activities like discussing, writing, presentation, and problem-solving or reflecting. The concept of deep active learning has recently enriched the concept of active learning. Matsushita (2018) presents a new concept of deep active learning as the type of learning that refers to learners' self-directed application of critical and creative thinking, problem-solving, communication, and collaboration. Active learning is an umbrella term and may cover the application of UDL principles in the learning process.

With widespread school closures during the COVID-19 pandemic, learners are temporarily being given distance education and they have started active learning outside of the classrooms. During this educational disruption, the learners were obliged and encouraged to test self-directed and active learning. It was about learning the course content and developing basic and essential features of self-directed learners.

Seeking a broader approach to expert learners' development, we selected the self-determination theory as a theoretical framework due to its conceptual breadth and applicability in inclusive education.

Comparing Self-Determined and Expert Learners help us to demonstrate how self-determination and expertise in learning are strongly related. Self-directed learners are on their way to becoming the experts of their learning processes (Biemiller \& Meichenbaum, 2017).

Comparisons among self-determined and expert learners' qualities reveal selfdetermination theory as a solid theoretical background for expert learners' conception.

Having the sufficient theoretical basis for the concept of expert learners (see Fig. 2.1), we begin to search for significant characteristics of expert learners that could help us identify key milestones that each student can aspire to become the best he or she can be. 
Fig. 2.1 Theoretical background for the development of expert learners

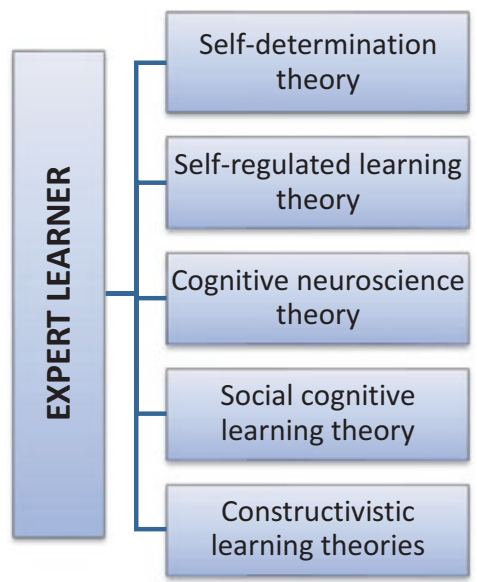

\subsection{Characteristics of Expert Learners in the Context of Inclusive Education}

The COVID-19 pandemic has disrupted schooling; therefore, inclusive education and development of expert learners must continue. Internals of expert learners should be interpreted with openness to diversity, change, and inclusive values sustainability.

According to Schwartz and Manning (2018a, b), active participation in learning processes distinguishes expert learners from classmates. We consider here several key differences of expert learners to reveal their dissimilarities wider.

Expert learners notice faster and understand deeper meaningful information. They organize information into domains around basic concepts more successfully. Their knowledge is not simply a list of facts and formulas relevant to some field. Consequently, expert learners organize, represent, and interpret information in more efficient ways. They more often mind the context of the applicability of knowledge. Expert learners make less attentional efforts when learning because learning material functions as a cognitive stimulant (Posner et al., 2010). They are more flexible in new situations. They are more likely to have metacognition (the ability to monitor their level of understanding and determine its adequacy). Expert learners want to learn deeply and know better how to learn and how they learn best.

In the minds of expert learners, both the problem and possible problem-solving strategies connect more strongly. When faced with a problem, they apply the known information and remember similar issues and strategies for solving them efficiently. The readily working retrieval system is specific for expert learners because they use short-term and long-term memory more efficiently without memorizing each piece of information.

Expert learners use stronger self-monitoring skills and better self-knowledge because they are more aware of when to verify the solutions, recognize their 
strengths and limitations, and where the error was made during the task. It helps them to manage their learning as well, initiating opportunities to learn, setting personal learning goals based upon their own needs, skills, and interests, selecting the most effective learning strategies, evaluating the effectiveness of selected learning strategies, modifying the learning goal or action plan, and adapting their behavior to learning situations. They are more skilled in self-reflection and reflect on their learning more often, evaluating their progress, and attributing successes to their competencies and failures to correctable causes. Expert learners are characterized by solid self-regulation due to good metacognitive skills and strong resilience and persistence when facing barriers to learning. Their ability to learn independently is better developed, and they manifest creativity and curiosity more often.

More often and on purpose, expert learners take responsibility for their learning because they understand how they learn and manage their education. Accountability and the opportunity to choose are related. Expert learners are looking for meaningful learning choices and enjoy every possibility to decide for themselves. Since they know their learning needs and interests, dispositions, and capacities, it is easy for them to watch over their choices' positive and negative consequences. Along these lines, they realize themselves as active agents in the learning process, get a voice in their learning, and develop a sense of ownership in the learning process. When expert learners can make the choices, they tend to feel more responsible for their learning.

Expert learners do not give up so quickly when confronted with obstacles and distractions but try to find novel and effective ways of resolving the situation. Perkins (2014) offered a list of personal and interpersonal skills and knowledge worth developing in the twenty-first century and showed us that expert learners recognize that their initial understanding is likely to be incorrect or too simple, motivating them to watch out for solutions.

Expert learners are more aware of themselves as learners knowing their strengths and areas for improvement. So, they are more adaptive because they do selfmonitoring while learning and have more learning strategies from which to choose.

Expert learners are more sensitive to task requirements due to greater metacognitive awareness. They can predict quite accurately which tasks are challenging and which are not. Expert learners more clearly comprehend why they fail and use the metacognitive awareness check for errors and redirect actions to attain a better solution. The most important questions they ask themselves are: How do we learn? How do we know that we have learned? How to direct our future learning? The DunningKruger effect (illusory superiority) does not work on expert learners who are relatively independent monitors of the task performance and usually do not overestimate their abilities. That difference points to a meaningful distinction of expert learners-well-developed metacognitive awareness.

It is important to note that expert learners customary have high-quality teachers who are partners in learning (Auerbach et al., 2018). They seek support from teachers and listen to advice, though they make their own decisions. It is probably clear without specific study that even expert learners need help to improve their learning.

Seeking to provide insights into the development of expert learners, understanding the dissimilarities of their inner qualities is necessary. Analysis of expert 
learners' differences could be very fruitful to determine the direction of actions for teachers who seek to develop the expert learners. Comparison of expert learners and learners in their way to expertise is valuable for giving specific guidelines for selfdevelopment of learners. Knowing what distinguishes expert learners from their classmates can help the teachers appropriately respond to the diversity of all learners. We write about dissimilarities of expert learners not because we do not believe that all learners can become experts, but because we aim to reveal how successful their learning learners look.

Scientists have long been trying to find out what characteristics are inherent for expert learners. Glaser and Chi (1988) listed and described seven key characteristics of experts: they excel mainly in their sphere; perceive large, meaningful problems in their sphere; are fast in performing the skills in their sphere; have superior shortterm and long-term memory; see and represent a problem in the deeper level; spend a great deal of time analysing the problem; and have strong self-monitoring skills. Ericsson and Smith (1991) reviewed a broad range of approaches to the structure of expertise and expert performance. These authors highlighted the experts' ability to evaluate their performance and explain the reasons for setbacks. Weinstein and Van Mater Stone (1993) affirm that general education models come from conceptions of expert performance. However, teachers believe that an expert just knew more about something. They have summarized the five characteristics of experts: knowing more, organized and integrated, having effective and efficient strategies for accessing and using knowledge, having different motivations for acquiring and using knowledge, and having self-regulation. Ertmer and Newby (1996) characterized expert learners as strategic, self-regulated, and reflective. They recognized the reflection on learning to be an essential ingredient in the development of expert learners. These authors presented expert learners as strategic strategy users who use the gained knowledge in real-life situations and seek to achieve desired learning goals by selecting, controlling, and monitoring different learning strategies. Expert learners control the processes necessary for successful learning through self-control. The components of self-regulation are creating plans, monitoring their implementation, and evaluating the results achieved. Zimmerman (2000) described the characteristics of good self-regulated learners to reveal in what way naïve learners differ from expert learners and highlighted planning, organization, self-observation, and self-evaluation. Bransford et al. (2000) defined expertise as a continuum that runs from novice to expert. They presented the characteristics of expert learners based on key scientific findings that have come from the study of people who have developed expertise. The authors stated that expertise should not be associated with intellectual level or some characteristics of the memory. The expert learners have extensive, relevant, well-organized, and grounded foundational concepts knowledge to support their learning and improve understanding. Two types of expert learners were distinguished: adaptive and routine expert learners. Adaptive ones can transfer knowledge from one domain to another when conditions change, whereas routine expert learners function merely in standard conditions. According to Bransford et al. (2000), expert learners notice important aspects of information, understand the subjects deeply, analyze the context of applicability, and put little attentional effort. Sternberg 
(2003) reviewed the expert learners' characteristics based on the theory of successful intelligence. Regretting the fact that many learners fail to learn up to their potential, the author indicated three kinds of expert learner-specific abilities: (1) analytical ability, which provides the expert learners with the opportunity to analyze, critique, judge, compare and contrast, evaluate, and assess; (2) creative ability which helps the expert learners to create, invent, discover, imagine if, suppose that, and predict; (3) practical ability which is needed for the expert learners to apply, use, put into practice, implement, employ, and render practical. According to the author, analytical abilities are necessary for an expert learner to determine whether ideas are good, creative abilities to generate ideas, and practical abilities to implement these ideas in practice. Chi (2006) analyzed two approaches to experts' characteristics: a fundamental approach to expertise as arising from chance or inner talent and a comparative approach as a level of proficiency that everyone can achieve. This author highlighted seven major ways in which experts excel: generating the best, fast, and accurate solution in solving a problem or designing tasks; perceiving the deep structure of a problem or situation; analyzing the problem qualitatively; having selfmonitoring skills; choosing the appropriate strategy; being opportunistic when using resources; and retrieving knowledge and strategies with minimal cognitive effort. Woolfolk (2008) revealed three characteristics of expert learners: they focus their attention on materials learned, give the effort to process the information deeply, and take responsibility for their learning. Rahman et al. (2010) pointed out one of the important characteristics of expert learners: controlling their learning through meta-attention and meta-comprehension. These authors clarified expert learners as having a specific goal at the beginning of the lesson to help them focus and, consequently, monitor and evaluate their learning outcomes. According to Wild and Heck (2011), expert learners have three main characteristics: they actively engage with the learning material, take responsibility for their learning, and practice selfregulated learning by motivating themselves and guiding their learning. Stobart (2014) looked into six characteristics of expert learners: they develop their skills, want to be successful, apply knowledge in practice, organize information by creating models, look for feedback to improve their learning, and improve self-regulation. Meyer et al. (2014) described expert learners as purposeful, motivated, resourceful, knowledgeable, strategic, and goal-directed. Bray and McClaskey (2016) described how expert learners (learners with agency) develop and detected some of their characteristics. They understand how to manage their learning environment, know where to look for resources, know who to connect to their learning networks so they can collaborate and consult in any learning situation, and know-how to learn from their mistakes and develop a new understanding. Persky and Robinson (2017) named inner motivation and self-regulation as necessary characteristics of the expert learners who focused on mastery, increasing knowledge base, constantly practicing, being open to new experiences, and persisting toward a learning goal. Williams et al. (2017) focused on perceptual-cognitive expertise. They stressed that expert learners recognize and use task-relevant information provided by classmates or teachers, use probabilities and expectations in different situations, and focus on application. 
McDowell (2019) attempted to identify the knowledge and skills learners must develop to become experts. They defined expert learners as persons who apply their knowledge and skills in various situations to solve problems and use orientation, activation, and collaboration skills to take control and improve their learning. According to this author, expert learners measure their knowledge and adapt learning strategies. They measure their performance, determine the following steps, reflect on their progress, and identify strategies to improve. They also visualize their understanding and give or receive feedback to improve learning for themselves, classmates, and teachers.

Darling-Hammond et al. (2020) emphasized the need to develop twenty-first century skills, which include:

- Critical thinking and problem-solving skills

- Capacity to find, analyze, synthesize, and apply knowledge to novel situations

- Interpersonal skills that allow people to work with others and engage effectively in cross-cultural contexts

- Self-directional abilities that enable them to manage their work and complex projects

- Capabilities to competently find resources and use tools

- Capacity to communicate effectively in many ways

- Strong self-regulation

- Executive functioning

- Metacognitive skills

- Resourcefulness, perseverance, and resilience in the face of obstacles and uncertainty

- Ability to learn independently; and curiosity, inventiveness, and creativity

This list of skills forms the belief that twenty-first-century learners are remarkably like expert learners as they have comparable abilities and qualities.

It is impossible to provide one single list of universal characteristics which can define an expert learner across all contexts and cultures. Current knowledge about neuroplasticity and the growth mindset directed our attention back to the universal design for learning and the qualities of an expert learner aligned with UDL guidelines.

\subsection{Profile of Expert Learners Based on the UDL}

According to the universal design for learning framework, expert learners are purposeful, motivated, resourceful, knowledgeable, strategic, and goal-directed. However, we can expand these properties.

1. Expert learners know what they want to achieve and why it is crucial. The goals they are setting are clear to them.

2. Expert learners possess high expectations and recognize that they can progress in achieving their goals. 
3. Expert learners know how to use relevant resources and adjust strategies and choices to reduce barriers to learning.

4. Expert learners understand that learning takes effort and appreciate masteryoriented feedback.

5. Expert learners see challenges as opportunities to learn and expand their knowledge.

6. Expert learners use introspection. They reflect on how resources have helped them overcome barriers to learning, why specific goals were not met, and how choices might be made more appropriately next time.

In the video, ${ }^{1}$ Professor David Rose, co-founder of the Centre for Applied Special Technology (CAST), talks about the expert learners as follows:

1. Expert learners are focused on a goal, influenced by internal motives, they do not need to be told what to do. They have plans, solve problems, invent, and learn how to make new things.

2. Expert learners are knowledgeable, but they want to know even more. They know how to find information and what information is valuable to them.

3. Expert learners take great care of their learning. They invest their emotions and feel pleasure when learning new things. They do not wait for someone to help them. They manage frustration and maintain their motivation and involvement even if they fail sometimes.

Meyer et al. (2014) suggested new insights into becoming a learning expert. The authors warned that expert learners do not necessarily know more than other learners and defined them as continually learning, growing, and improving. According to the authors, the key to expert learning is self-knowledge. Therefore, expert learners are self-aware and active: they know how to solve problems flexibly, change or adapt after mistakes, and select learning strategies successfully. They know how to engage deeply in their learning: to learn in a social context, observe other people as models, and change the approach after receiving feedback. Expert learners make an effort to elaborate and improve their skills and abilities and know that learning is a continuous process.

Expert learners have been defined comprehensively by the CAST (2018) when scientists who worked there looked at neuroscience and cognitive science. They integrated the characteristics of expert learners into three units: (1) purposeful and motivated expert learners, (2) resourceful and knowledgeable expert learners, (3) strategic and goal-directed expert learners.

Each of these three characteristics of expert learners has more detailed qualities (see Tables 2.1, 2.2, and 2.3 in the Appendix) based on the theory of selfdetermination and four versions of the UDL Guidelines (CAST, 2008, 2011, 2014, 2018). We present the qualities of expert learners on three levels, from more abstract to more specific ones (Qualities 1, Qualities 2, and Qualities 3).

\footnotetext{
${ }^{1}$ https://www.youtube.com/watch?v=8HykYqfn79c.
} 
As presented in Table 2.1 (see the Appendix), purposeful and motivated expert learners are interested, uphold effort and persistence, and self-regulating. The main qualities of these learners are as follows:

- These learners are attentive and engaged through choice and autonomy. They prioritize authenticity, value, and relevance. Furthermore, they are resistant to barriers, distractions, and threats.

- These learners are persistent. They demonstrate concentration when learning. They set essential goals and objectives, identify suitable resources. They value collaboration and feedback.

- These learners exemplify self-regulation through positive expectations and beliefs. They cope with stress and use self-reflection and self-assessment.

The first UDL principle of providing multiple means of engagement is closely related to the qualities of purposeful and motivated expert learners listed above.

Resourceful and Knowledgeable Expert Learners These are portrayed in Table 2.2 (see the Appendix) as perceiving, mastering language and symbols, and comprehending. The main qualities of these learners are as follows:

- These learners percept through access and adjustment of information in different modalities. They use alternatives for visual and auditory information.

- These learners recognize, memorize and internalize of language symbols. They do it through information decoding, syntax and structure understanding.

- These learners comprehend through background knowledge, fundamental relationships, patterns, ideas, and features. They transfer, generalize process, and visualize.

The second UDL principle of providing multiple means of representation is closely related to the qualities of resourceful and knowledgeable expert learners listed above.

Strategic and Goal-Directed Expert Learners These are described in Table 2.3 (see Appendix) as operating physical actions, mastering expression and communication, and carrying out executive functions. The main qualities of these learners are as follows:

- These learners like physical activity. They seek it through varied learning methods and technologies.

- These learners use communication and expression through multimedia. They like multiple tools, practice, and performance.

- These learners perform executive functioning through management of resources. They are setting goals, planning strategies, and monitoring progress.

These qualities of strategic and goal-directed expert learners listed above are closely related to the third UDL principle of providing multiple means of action and expression. 


\subsection{Discussion and Conclusions}

In inclusive education and application of UDL strategy for the development of expert learners, we considered which qualities of expert learners are the most essential because these would be presented in tables. We evaluated priorities keeping in mind the teachers' activities when developing these learners. For example, if the teachers' goal is to stimulate the interest in learning, we determined that the most crucial quality of expert learners was "being interested" (i.e. maintaining their attention and engagement). Identifying some of the critical attributes of expert learners and thoroughly analysing how they relate to the three fundamental characteristics examined by the UDL guideline could serve as a road map for teachers who want to carry out significant activities concerning the development of expert learners.

An expert in society has special skills or knowledge about a particular subject derived from extensive experience. An expert learner in the classroom is someone who is in the process of becoming an expert, mastering his or her specific knowledge, skills, and beliefs (Persky \& Robinson, 2017). Meyer et al. (2014) present expertise not as a destination but as a process of becoming more expert because learning is a process of continuous change and growth.

Most scientists who investigated the developmental process of the expert learner believed that every student could become an expert learner because everyone can develop. Expert learners are nurtured through their motivation to overcome difficulties, practice, reflection on where they are challenged, self-regulation, executive functioning, situational awareness, and reduction or surmounting barriers (Meyer et al., 2014; McClaskey, 2016; Tobin \& Behling, 2018). It seems that the key to expert learning is the personification of the self as a learner through an awareness of one's needs, strengths, and challenges (Hollins, 2018). Hartman (2015) affirms that all students are expert learners. Such a statement needs clarification as becoming an expert learner requires an empowering and supportive environment.

The students who had problems in learning must have the potential to develop as expert learners through the promotion of greater independence, achievability of learning goals, use of accessible learning materials, and enhancement of skills and knowledge. Learners with disabilities, like all learners, should be included and have access to multiple means of representation, action, and expression.

Darling-Hammond et al. (2020) posit that knowledge is rapidly expanding in the twenty-first century. The ability to find, analyze, synthesize, and apply knowledge to novel situations is essential nowadays. The development of such skills requires a different kind of teaching and learning in which the learning reveals itself as not the reception of facts and teaching as not the transmission of information.

We used Deci and Ryan's $(1985,2012)$ self-determination theory as a theoretical framework for the expert learners' concept due to its conceptual breadth and applicability in inclusive education.

Purposeful and motivated expert learners are engaged in learning, desirous for new knowledge, and motivated by learning itself. They know how to set learning goals for themselves and sustain effort and resilience when reaching those goals. They monitor and regulate emotional reactions that would distract them from 
successful learning. Purposeful and motivated expert learners can reflect on their education without having to be asked to do so. They reflect on what is going well or worse and find the areas to improve, relying on current strengths. In this way, they can make learning more personal. When the learning material is not necessarily interesting for them, they find the means to connect it to something fascinating to them.

Resourceful and knowledgeable expert learners are mastering language and symbols and comprehending. They recognize the tools and resources that would help them find, structure, and remember new information. They know how to identify, prioritize, and assimilate new information presented in the classroom and how to transform that information into meaningful and usable knowledge that they can put into practice. Resourceful and knowledgeable expert learners can apply the tools, methods, and resources that support the learning process and-this is very important-they also fearlessly ask the teachers for instructional scaffolding to facilitate their learning and help in the mastery of tasks. They are looking for means to comprehend clearly and to redevelop or to reconceptualise the learning material.

Strategic and goal-directed expert learners are operating physical actions, mastering expression and communication, and caring for executive functions. They usually have learning goals in mind and therefore possess the plans to achieve these goals. So they need to monitor their learning and employ effective learning strategies to optimize it, rejecting the process that turned out to be ineffective. Strategic and goal-directed expert learners are developing strong metacognitive skills. For that purpose, they seek to assess themselves as having some strengths and weaknesses and reinforce their strengths and work on their weaknesses. Strategic and goal-directed learners develop their executive functions using different tools and means effectively. They are looking for possibilities to be active and strategical when learning.

The concept of "development of expert learner" in some countries' education systems (e.g. Lithuanian and Polish) is entirely new. The terms "teacher experts", "student support experts", and eventually "education experts" are already used, but "expert learner" is not yet. Specific Austrian, Finnish, Lithuanian, and Polish schools have already applied action research, and teachers have already implemented UDL principles for the development of expert learners. Upon completing this research, we can state that students' development to become expert learners was undoubtedly challenging. Sharma et al. (2019) investigated the barriers to implementing inclusive education and identified the most significant obstacle: inadequate teacher preparation. The teachers and researchers of Austria, Finland, Lithuania, and Poland have had particular and valuable experiences applying inclusive education principles through the UDL strategy.

In summary, teachers can nurture purposeful, motivated, resourceful, knowledgeable, strategic, and goal-directed learners who understand the importance of such qualities. By creating personalized learning environments, supporting learning, developing critical skills, and monitoring progress, teachers can work with their students to help them become expert learners. The following chapters of this book will reveal how schools have implemented the principles of the universal design for learning framework to develop more expert learners. 


\section{Appendix: Qualities of Expert Learners}

Table 2.1 Qualities of purposeful and motivated expert learners

\begin{tabular}{|c|c|c|}
\hline Qualities 1 & Qualities 2 & Qualities 3 \\
\hline \multirow[t]{3}{*}{$\begin{array}{l}\text { 1. Interested } \\
\text { (maintaining their } \\
\text { attention and } \\
\text { engagement) }\end{array}$} & 1.1. Autonomous & $\begin{array}{l}\text { 1.1.1. Chooses the learning objectives themselves } \\
\text { 1.1.2. Chooses how to reach objectives and employ } \\
\text { available tools or supports } \\
\text { 1.1.3. Feels proud because of their accomplishment } \\
\text { and stays connected to their learning } \\
\text { 1.1.4. Selects the right kind of choice and } \\
\text { demonstrates an adequate level of independence } \\
\text { 1.1.5. Evaluates the level of challenge, possible } \\
\text { rewards, or recognition } \\
\text { 1.1.6. Practices and assesses their skills } \\
\text { 1.1.7. Sets their personal academic goals }\end{array}$ \\
\hline & $\begin{array}{l}\text { 1.2. Orientates to } \\
\text { authenticity, value, } \\
\text { and relevance }\end{array}$ & $\begin{array}{l}\text { 1.2.1. Accumulates information and performs } \\
\text { activities that are relevant and valuable to their } \\
\text { interests and goals } \\
\text { 1.2.2. Believes in the utility and relevance of learning } \\
\text { 1.2.3. Performs authentic and meaningful activities } \\
\text { through active participation, exploration, and } \\
\text { experimentation. } \\
\text { 1.2.4. Implements personal evaluation and self- } \\
\text { reflection to learning content and learning activities } \\
\text { 1.2.5. Uses imagination when solving novel and } \\
\text { unusual problems or analysing complex ideas } \\
\text { creatively }\end{array}$ \\
\hline & $\begin{array}{l}\text { 1.3. Picking up } \\
\text { with distractions, } \\
\text { barriers, and threats }\end{array}$ & $\begin{array}{l}\text { 1.3.1. Overcomes or reduces the potential threats and } \\
\text { distractions contained in the learning environment } \\
\text { 1.3.2. Changes the level of novelty or risk } \\
\text { 1.3.3. Uses tools that can increase the predictability of } \\
\text { daily learning activities and changes in it } \\
\text { 1.3.4. Searches for something novel, surprising, and } \\
\text { unexpected when performing the highly routinized } \\
\text { activities } \\
\text { 1.3.5. Maintains an adequate level of sensory } \\
\text { stimulation } \\
\text { 1.3.6. Actively participates in whole-class discussions }\end{array}$ \\
\hline
\end{tabular}


Table 2.2 (continued)

\begin{tabular}{|c|c|c|}
\hline Qualities 1 & Qualities 2 & Qualities 3 \\
\hline \multirow[t]{4}{*}{$\begin{array}{l}\text { 2. Upholds effort } \\
\text { and persistence } \\
\text { (controls their } \\
\text { attention and } \\
\text { affection to } \\
\text { maintain } \\
\text { concentration } \\
\text { when learning) }\end{array}$} & $\begin{array}{l}\text { 2.1. Considers } \\
\text { goals and objectives } \\
\text { important }\end{array}$ & $\begin{array}{l}\text { 2.1.1. Foresees the rewards of reaching their goals } \\
\text { 2.1.2. Sustains efforts and concentration when } \\
\text { confronted with distraction } \\
\text { 2.1.3. Divides long-term goals into short-term } \\
\text { objectives } \\
\text { 2.1.4. Uses scheduling tools. } \\
\text { 2.1.5. Visualizes the desired outcome } \\
\text { 2.1.6. Participates in assessment discussions about } \\
\text { excellence }\end{array}$ \\
\hline & $\begin{array}{l}\text { 2.2. Optimizes the } \\
\text { challenge through } \\
\text { diversification of } \\
\text { resources }\end{array}$ & $\begin{array}{l}\text { 2.2.1. Needs to be challenged } \\
\text { 2.2.2. Searches and finds the suitable and beneficial } \\
\text { resources necessary for successful completion of the } \\
\text { learning tasks } \\
\text { 2.2.3. Finds challenges that can optimally motivate } \\
\text { them }\end{array}$ \\
\hline & $\begin{array}{l}\text { 2.3. Fosters } \\
\text { collaboration }\end{array}$ & $\begin{array}{l}\text { 2.3.1. Communicates and collaborates effectively } \\
\text { 2.3.2. Knows when and how to ask for support } \\
\text { 2.3.3. Provides support by themselves } \\
\text { 2.3.4. Holds the expectations for group work }\end{array}$ \\
\hline & $\begin{array}{l}\text { 2.4. Aspires for } \\
\text { mastery-oriented } \\
\text { feedbacks }\end{array}$ & $\begin{array}{l}\text { 2.4.1. Seeks for mastery-oriented, relevant, } \\
\text { constructive, substantive, informative, accessible, } \\
\text { consequential, and timely feedbacks } \\
\text { 2.4.2. Supports the self-motivation and efforts } \\
\text { essential to their learning } \\
\text { 2.4.3. Maintains perseverance } \\
\text { 2.4.4. Maintains self-efficacy and self-awareness } \\
\text { 2.4.5. Uses specific supports and strategies when } \\
\text { challenged } \\
\text { 2.4.6. Identifies patterns of errors and wrong answers } \\
\text { to succeed in the future }\end{array}$ \\
\hline \multirow[t]{3}{*}{$\begin{array}{l}\text { 3. Self-regulating } \\
\text { (strategically } \\
\text { modulates their } \\
\text { emotional and } \\
\text { behavioral } \\
\text { reactions to be } \\
\text { more effective in } \\
\text { learning) }\end{array}$} & $\begin{array}{l}\text { 3.1. Maintains } \\
\text { motivation through } \\
\text { expectations and } \\
\text { beliefs }\end{array}$ & $\begin{array}{l}\text { 3.1.1. Knows about what they find motivating } \\
\text { 3.1.2. Has positive beliefs that their goals can be } \\
\text { reached } \\
\text { 3.1.3. Copes with frustration, outbursts of anger, and } \\
\text { anxiety when reaching their goals } \\
\text { 3.1.4. Increases the length of performance in the face } \\
\text { of distractions } \\
\text { 3.1.5. Increases the frequency of self-reflection and } \\
\text { self-reinforcements } \\
\text { 3.1.6. Considers both their strengths and limitations }\end{array}$ \\
\hline & $\begin{array}{l}\text { 3.2. Fosters } \\
\text { personal coping } \\
\text { skills and strategies }\end{array}$ & $\begin{array}{l}\text { 3.2.1. Copes with their emotional responses to some } \\
\text { internal or external events } \\
\text { 3.2.2. Seeks external emotional support } \\
\text { 3.2.3. Develops and demonstrates self-control and } \\
\text { coping skills } \\
\text { 3.2.4. Handles specific phobias and negative } \\
\text { judgments about their aptitudes }\end{array}$ \\
\hline & $\begin{array}{l}\text { 3.3. Employs } \\
\text { self-assessment and } \\
\text { reflection }\end{array}$ & $\begin{array}{l}\text { 3.3.1. Monitors their emotions and reactivity } \\
\text { 3.3.2. Uses metacognition purposefully } \\
\text { 3.3.3. Identifies and uses different and optimal } \\
\text { self-assessment techniques } \\
\text { 3.3.4. Monitors changes in their performance }\end{array}$ \\
\hline
\end{tabular}


Table 2.2 Qualities of resourceful and knowledgeable expert learners

\begin{tabular}{|c|c|c|}
\hline Qualities 1 & Qualities 2 & Qualities 3 \\
\hline \multirow{3}{*}{$\begin{array}{l}\text { 1. Perceives (accesses and } \\
\text { adjusts information } \\
\text { through different } \\
\text { modalities) }\end{array}$} & $\begin{array}{l}\text { 1.1. Chooses ways to } \\
\text { display information }\end{array}$ & $\begin{array}{l}\text { 1.1.1. Perceives information clearly } \\
\text { 1.1.2. Makes connections within and } \\
\text { between concepts effectively }\end{array}$ \\
\hline & $\begin{array}{l}\text { 1.2. Uses alternatives for } \\
\text { auditory information }\end{array}$ & $\begin{array}{l}\text { 1.2.1. Uses text and visual equivalents } \\
\text { and written transcripts when needed } \\
\text { 1.2.2. Uses visual analogues to represent } \\
\text { emphasis. }\end{array}$ \\
\hline & $\begin{array}{l}\text { 1.3. Uses alternatives for } \\
\text { visual information }\end{array}$ & $\begin{array}{l}\text { 1.3.1. Uses text or sound descriptions for } \\
\text { images, graphics, video, or animations } \\
\text { 1.3.2. Uses touch equivalents } \\
\text { 1.3.4. Uses physical objects and spatial } \\
\text { models }\end{array}$ \\
\hline \multirow[t]{5}{*}{$\begin{array}{l}\text { 2. Masters language and } \\
\text { symbols (recognizes and } \\
\text { memorizes language } \\
\text { symbols in learning } \\
\text { materials and internalizing } \\
\text { them for thinking on) }\end{array}$} & $\begin{array}{l}\text { 2.1. Understands the } \\
\text { vocabulary and symbols }\end{array}$ & $\begin{array}{l}\text { 2.1.1. Associates representations of their } \\
\text { meaning } \\
\text { 2.1.2. Connects vocabulary and symbols } \\
\text { to their experience and prior knowledge } \\
\text { 2.1.3. Uses graphic symbols with } \\
\text { alternative text descriptions } \\
\text { 2.1.4. Transforms complex information } \\
\text { to simpler ones } \\
\text { 2.1.5. Searches for support when facing } \\
\text { unfamiliar information }\end{array}$ \\
\hline & $\begin{array}{l}\text { 2.2. Understanding the } \\
\text { syntax and structure }\end{array}$ & $\begin{array}{l}\text { 2.2.1. Combines single elements of } \\
\text { meaning to make new meanings } \\
\text { 2.2.2. Understands the rules, structures, } \\
\text { and structural relations } \\
\text { 2.2.3. Makes connections to previously } \\
\text { learned structures } \\
\text { 2.2.4. Makes relationships between } \\
\text { elements }\end{array}$ \\
\hline & $\begin{array}{l}\text { 2.3. Employs the } \\
\text { decoding of the } \\
\text { information }\end{array}$ & $\begin{array}{l}\text { 2.3.1. Decodes information presented in } \\
\text { an encoded format } \\
\text { 2.3.2. Comprehends and processes } \\
\text { information } \\
\text { 2.3.3. Uses the lists of key terms }\end{array}$ \\
\hline & $\begin{array}{l}\text { 2.4. Understands across } \\
\text { languages }\end{array}$ & $\begin{array}{l}\text { 2.4.1. Uses both domain-specific and } \\
\text { standard terms. }\end{array}$ \\
\hline & $\begin{array}{l}\text { 2.5. Illustrates through } \\
\text { multimedia }\end{array}$ & $\begin{array}{l}\text { 2.5.1. Uses multimedia to make } \\
\text { information more understandable and } \\
\text { accessible }\end{array}$ \\
\hline
\end{tabular}


Table 2.2 (continued)

\begin{tabular}{|c|c|c|}
\hline Qualities 1 & Qualities 2 & Qualities 3 \\
\hline \multirow[t]{4}{*}{$\begin{array}{l}\text { 3. Comprehends (actively } \\
\text { transforms accessible } \\
\text { information into useable } \\
\text { knowledge) }\end{array}$} & $\begin{array}{l}\text { 3.1. Possesses the } \\
\text { background knowledge }\end{array}$ & $\begin{array}{l}\text { 3.1.1. Assembles the necessary } \\
\text { knowledge } \\
\text { 3.1.2. Accumulates the background } \\
\text { knowledge } \\
\text { 3.1.3. Activates prior knowledge } \\
\text { 3.1.4. Uses knowledge organizers } \\
\text { 3.1.5. Connects concepts with relevant } \\
\text { analogies } \\
\text { 3.1.6. Understands cross-curricular } \\
\text { connections }\end{array}$ \\
\hline & $\begin{array}{l}\text { 3.2. Grasps the } \\
\text { fundamental } \\
\text { relationships, patterns, } \\
\text { ideas, and features }\end{array}$ & $\begin{array}{l}\text { 3.2.1. Distinguishes what is essential } \\
\text { from what is unimportant } \\
\text { 3.2.2. Assimilates the valuable } \\
\text { information into available knowledge } \\
\text { 3.2.3. Uses learned skills to solve } \\
\text { problems }\end{array}$ \\
\hline & $\begin{array}{l}\text { 3.3. Implements the } \\
\text { information processing } \\
\text { and visualization }\end{array}$ & $\begin{array}{l}\text { 3.3.1. Uses cognitive strategies to } \\
\text { summarize, categorize, prioritize, } \\
\text { contextualize, and remember the } \\
\text { information } \\
\text { 3.3.2. Uses information processing } \\
\text { strategies successfully } \\
\text { 3.3.3. Divides information into more } \\
\text { minor elements } \\
\text { 3.3.4. Removes distractions }\end{array}$ \\
\hline & $\begin{array}{l}\text { 3.4. Employs the transfer } \\
\text { and generalization }\end{array}$ & $\begin{array}{l}\text { 3.4.1. Transfers their knowledge to new } \\
\text { contexts } \\
\text { 3.4.2. Uses mnemonic strategies and } \\
\text { devices } \\
\text { 3.4.3. Seeks for opportunities to review } \\
\text { and practice } \\
\text { 3.4.4. Installs new ideas in customary } \\
\text { contexts } \\
\text { 3.4.5. Generalizes learning to new } \\
\text { situations } \\
\text { 3.4.6. Reconsiders ideas and links } \\
\text { between ideas }\end{array}$ \\
\hline
\end{tabular}


Table 2.3 Qualities of strategic and goal-directed expert learners

\begin{tabular}{|c|c|c|}
\hline Qualities 1 & Qualities 2 & Qualities 3 \\
\hline \multirow{2}{*}{$\begin{array}{l}\text { 1. Operates } \\
\text { physical actions } \\
\text { (using learning } \\
\text { strategies leaned } \\
\text { on the actions) }\end{array}$} & $\begin{array}{l}\text { 1.1. Uses varied } \\
\text { methods when } \\
\text { performing the } \\
\text { learning tasks }\end{array}$ & $\begin{array}{l}\text { 1.1.1. Manages the motor demands of the tasks } \\
\text { 1.1.2. Uses multiple means for actions } \\
\text { 1.1.3. Interacts with materials physically }\end{array}$ \\
\hline & $\begin{array}{l}\text { 1.2. Exploits varied } \\
\text { tools and } \\
\text { technologies }\end{array}$ & $\begin{array}{l}\text { 1.2.1. Uses the tools effectively } \\
\text { 1.2.2. Uses tools for full participation in learning }\end{array}$ \\
\hline \multirow{3}{*}{$\begin{array}{l}\text { 2. Masters } \\
\text { expression and } \\
\text { communication } \\
\text { (uses alternative } \\
\text { means for the } \\
\text { expression of } \\
\text { ideas and } \\
\text { concepts) }\end{array}$} & $\begin{array}{l}\text { 2.1. Uses } \\
\text { multimedia for } \\
\text { communication }\end{array}$ & $\begin{array}{l}\text { 2.1.1. Uses a wide range of expression } \\
\text { 2.1.2. Composes in multimedia successfully } \\
\text { 2.1.3. Uses physical manipulatives } \\
\text { 2.1.4. Uses social media and interactive web tools } \\
\text { 2.1.5. Solves problems using a variety of strategies }\end{array}$ \\
\hline & $\begin{array}{l}\text { 2.2. Uses multiple } \\
\text { tools for } \\
\text { construction and } \\
\text { composition }\end{array}$ & $\begin{array}{l}\text { 2.2.1. Uses different software, webs, applications, and } \\
\text { tools }\end{array}$ \\
\hline & $\begin{array}{l}\text { 2.3. Looks for } \\
\text { support in practice } \\
\text { and performance }\end{array}$ & $\begin{array}{l}\text { 2.3.1. Seeks a variety of flows } \\
\text { 2.3.2. Practices independence } \\
\text { 2.3.3. Searches opportunities for performance } \\
\text { 2.3.4. Performs their learning in personally relevant } \\
\text { ways } \\
\text { 2.3.5. Seeks personalized feedback } \\
\text { 2.3.6. Uses novel solutions to authentic problems }\end{array}$ \\
\hline \multirow{4}{*}{$\begin{array}{l}\text { 3. Carries out the } \\
\text { executive } \\
\text { functions (sets } \\
\text { goals, plans } \\
\text { effective } \\
\text { strategies for } \\
\text { reaching those } \\
\text { goals, monitors } \\
\text { progress, and } \\
\text { modifies } \\
\text { approach as } \\
\text { needed, and } \\
\text { overcomes } \\
\text { impulsive } \\
\text { reactions) }\end{array}$} & $\begin{array}{l}\text { 3.1. Sets the } \\
\text { appropriate goals }\end{array}$ & $\begin{array}{l}\text { 3.1.1. Sets appropriate goals to guide their work } \\
\text { 3.1.2. Sets the goals effectively } \\
\text { 3.1.3. Assesses efforts, resources, and difficulties }\end{array}$ \\
\hline & $\begin{array}{l}\text { 3.2. Implements the } \\
\text { planning and varied } \\
\text { strategies }\end{array}$ & $\begin{array}{l}\text { 3.2.1. Plans the strategies to reach the goals } \\
\text { 3.2.2. Uses strategic planning } \\
\text { 3.2.3. Uses "stop and think" strategy } \\
\text { 3.2.4. Uses "show and explain" strategy } \\
\text { 3.2.5. Sets up priorities, sequences, and schedules of } \\
\text { steps after understanding the problem } \\
\text { 3.2.6. Uses "think-aloud" strategy } \\
\text { 3.2.7. Breaks long-term goals into short-term } \\
\text { objectives }\end{array}$ \\
\hline & $\begin{array}{l}\text { 3.3. Manages the } \\
\text { information and } \\
\text { resources }\end{array}$ & $\begin{array}{l}\text { 3.3.1. Uses organizers and models for collection and } \\
\text { organization of information } \\
\text { 3.3.2. Categorizes and systematizes the information } \\
\text { 3.3.3. Uses note-taking. }\end{array}$ \\
\hline & $\begin{array}{l}\text { 3.4. Monitors } \\
\text { progress }\end{array}$ & $\begin{array}{l}\text { 3.4.1. Has a clear and correct picture of their progress } \\
\text { 3.4.2. Knows what to improve } \\
\text { 3.4.3. Seeks feedback that is more accessible, timely, } \\
\text { informative, and explicit } \\
\text { 3.4.4. Monitors their progress effectively and guides } \\
\text { their effort and activity by using the monitoring } \\
\text { information } \\
\text { 3.4.5. Asks questions to themselves } \\
\text { 3.4.6. Spotting representations of their progress. } \\
\text { 3.4.7. Self-reflects on quality and completeness } \\
\text { 3.4.8. Self-assesses by multiple means }\end{array}$ \\
\hline
\end{tabular}




\section{References}

Ainscow, M. (2020). Inclusion and equity in education: Making sense of global challenges. PROSPECTS. Comparative Journal of Curriculum, Learning, and Assessment, 49, $123-134$.

Allegra, M., Seyed-Allaei, S., Schuck, N., Amati, D., Laio, A., \& Reverberi, C. (2020). Brain network dynamics during spontaneous strategy shifts and incremental task optimization. NeuroImage, 217, 116854. https://doi.org/10.1016/j.neuroimage.2020.116854

Alonso, A., Van der Meij, J., Tse, D., \& Genzel, L. (2020). Naïve to expert: Considering the role of previous knowledge in memory. Brain and Neuroscience Advances, 4, 1-17. https://doi. org/10.1177/2398212820948686

Auerbach, A., Higgins, M., Brickman, P., \& Andrews, T. (2018). Teacher knowledge for activelearning instruction: Expert-novice comparison reveals differences. CBE-Life Sciences Education, 17(1), 1-14.

Bali, M., \& Caines, A. (2018). A call for promoting ownership, equity, and agency in faculty development via connected learning. International Journal of Educational Technology in Higher Eduction, 15, 46. https://doi.org/10.1186/s41239-08-0128-8.

Bandura, A. (1991). Social cognitive theory of self-regulation. Organizational Behavior and Human Decision Processes, 50(2), 248-287.

Biemiller, A., \& Meichenbaum, D. (2017). The nature and nurture of the self-directed learners. In D. Meichenbaum (Ed.), The evolution of cognitive behaviour therapy (pp. 89-98). Routlegde.

Bigby, C., \& Douglas, J. (2020). Supported decision making. In R. Stancliffe, M. Wehrmeyer, K. Shogren, \& K. Abery (Eds.), Choice, preference, and disability: Promoting selfdetermination across the lifespan (pp. 45-66). Springer.

Bilalić, M., \& Campitelli, G. (2018). Studies of the activation and structural changes of the brain associated with expertise. In K. Ericsson, R. Hoffman, A. Kozbelt, \& M. A. Williams (Eds.), The Cambridge handbook of expertise and expert performance (pp. 233-256). Cambridge University Press.

Black, R., Weinberg, L., \& Brodwin, M. (2015). Universal Design for Learning and instruction: Perspectives of students with disabilities in higher education. Exceptionality Education International, 25(2), 1-16.

Bransford, J., Brown, A., \& Copcking, R. (2000). How people learn: Brain, mind, experience, and school. National Academies Press.

Bray, B., \& McClaskey, K. (2016). How to personalize learning: A practical guide for getting started and going deeper. Corwin.

Bruner, J. (1977). The process of education. Harvard University Press.

Cantor, P., Osher, D., Berg, J., Steyer, L., \& Rose, T. (2018). Malleability, plasticity, and individuality: How children learn and develop in context. Applied Developmental Science, 23(4), 307-337. https://www.researchgate.net/deref/https\%3A\%2F\%2Fdoi.org\%2F10.108 0\%2F10888691.2017.1398649

CAST. (2008). Universal design for learning guidelines version 1.0. Author.

CAST. (2011). Universal design for learning guidelines version 2.0. Author.

CAST. (2014). Universal design for learning guidelines version 2.1. Author.

CAST. (2018). Universal Design for Learning Guidelines version 2.2. Retrieved from http://udlguidelines.cast.org

Chambless, C., McCormick, S., Ipsen, C., Kurth, N., \& Hall, J. (2019). Teaching self-determination to youth with disabilities: The ASPIRE model. Journal of Vocational Rehabilitation, 51(2), $199-210$.

Chi, M. (2006). Two approaches to the study of experts' characteristics. In K. Ericsson, N. Charness, P. Feltovich, \& R. Hoffman (Eds.), The Cambridge handbook of expertise and expert performance (pp. 21-30). Cambridge University Press. 
Cook, S. C., \& Rao, K. (2018). Systematically applying UDL to effective practices for students with learning disabilities. Learning Disability Quarterly, 41(3), 179-191.

European Agency for Special Needs and Inclusive Education. (2019). Changing role of specialist provision in supporting inclusive education: Mapping specialist provision approaches in European countries. Retrieved September 21, 2020, from https://www.european-agency.org/ sites/default/files/CROSP_Synthesis_Report.pdf

European Commission. (2018). Council recommendation on common values, inclusive education, and the European dimension of teaching (2018). Retrieved February 8, 2021, from https:// ec.europa.eu/education/education-in-the-eu/council-recommendation-on-common-valuesinclusive-education-and-the-european-dimension-of-teaching_en

Evmenova, A. (2018). Preparing teachers to use universal design for learning to support diverse learners. Journal of Online Learning Reseach, 4(2), 147-171.

Dalton, E. M., Lyner-Cleophas, M., Ferguson, B. T., \& McKenzie, J. (2019). Inclusion, universal design, and universal design for learning in higher education: South Africa and the United States. African Journal of Disability, 8, 519.

Darling-Hammond, L., Flook, L., Cook-Harvey, C., Barron, B., \& Osher, D. (2020). Implications for educational practice of the science of learning and development. Applied Developmental Science, 24(2), 97-140. https://doi.org/10.1080/10888691.2018.1537791

Deci, E., \& Ryan, R. (1985). Intrinsic motivation and self-determination in human behavior. Plenum.

Deci, E., \& Ryan, R. (2012). Self-determination theory. In P. A. M. Van Lange, A. W. Kruglanski, \& E. T. Higgins (Eds.), Handbook of theories of social psychology (pp. 416-436). Sage Publications Ltd.

Denney, S., \& Daviso, A. (2012). Self-determination: A critical component of education. American Secondary Education, 40(2), 43-51.

du Toit-Brits, C., \& van Zyl, C.-M. (2017). Self-directed learning characteristics: Making learning personal, empowering, and successful. Africa Education Review, 14(3-4), 122-141.

Efklides, A. (2011). Interactions of metacognition with motivation and affect in self-regulated learning: The MASRL model. Educational Psychologist, 46(1), 6-25.

Efklides, A. (2019). Gifted students and self-regulated learning: The MASRL model and its implications for SRL. High Ability Studies, 30(1-2), 79-102.

Ericsson, K., \& Smith, J. (1991). Prospects and limits of the empirical study of expertise: An introduction. In K. Ericsson \& J. Smith (Eds.), Toward a general theory of expertise: Prospects and limits (pp. 1-38). Cambridge University Press.

Ertmer, P., \& Newby, T. (1996). The expert learners: Strategic, self-regulated, and reflective. Instructional Science, 24, 1-24.

Fandakova, Y., \& Hartley, C. (2020). Mechanisms of learning and plasticity in childhood and adolescence. Developmental Cognitive Neuroscience, 42, 100764. https://doi.org/10.1016/j. den.2020.100764

Field, S., \& Hoffman, A. (1994). Development of a model for self-determination. Career Development and Transition for Exceptional Individuals, 17(2), 159-169.

Freeman, S., Eddy, S., McDonough, M., Smith, M., Okoroafor, N., Jordt, H., \& Wenderoth, M. P. (2014). Active learning increases student performance in science, engineering, and mathematics. Proceedings of the National Academy of Sciences, 111(23), 8410-8415.

Gaumer Erickson, A., Noonan, P., Zheng, C., \& Brussow, J. (2015). The relationship between self-determination and academic achievement for adolescents with intellectual disabilities. Research in Developmental Disabilities, 36, 45-54.

Giannini, S. (2021). Time to roll out education's recovery package. UNESCO. Retrieved April 8, 2021, from https://en.unesco.org/news/time-roll-out-educations-recovery-package

Glaser, R., \& Chi, M. (1988). Overview. In M. Chi, R. Glaser, M. Farr, \& M. (Eds.), The nature of expertise (pp. 1-5). Psychology Press.

Global Education Monitoring Report Team. (2020). Global education monitoring report, 2020: Inclusion and education: All means all, easy to read version, key messages, recommendation. UNESCO. Retrieved February 8, 2021, from https://unesdoc.unesco.org/ark:/48223/ pf0000373724 
Griful-Freixenet, J., Struyven, K., Vantieghem, W., \& Gheyssens, E. (2020). Exploring the interrelationship between Universal Design for Learning (UDL) and Differentiated Instruction (DI): A systematic review. Educational Research Review, 29, 100306.

Gruber, M., Valji, A., \& Ranganath, C. (2019). Curiosity and learning: A neuroscientific perspective. In K. Renninger \& S. Hidi (Eds.), The Cambridge handbook of motivation and learning (pp. 397-417). Cambridge University Press.

Hagiwara, M., Shogren, K., Lane, K., Raley, S., \& Smith, S. (2020). A coaching framework of the self-determined learning model of instruction. Education and Training in Autism and Developmental Disabilities, 55, 17-27.

Hartman, E. (2015). Universal design for learning (UDL) and learners with severe support needs. International Journal of Whole Schooling, 11(1), 54-67.

Hartwigsen, G. (2018). Flexible redistribution in cognitive networks. Trends in Cognitive Science, 22(8), 687-698

Hoffman, A., \& Field, S. (2005). Steps for self-determination: A Curriculum to help adolescents learn to achieve their goals. Pro Ed.

Hollins, P. (2018). Accelerated learning for expertise: Rapid knowledge acquisition skills to learn faster, comprehend deeper, and reach a world-class level. PH Learning Inc.

Hornby, G. (2015). Inclusive special education: Development of a new theory for the education of children with special educational needs and disabilities. British Journal of Special Education, 42(3), 234-256.

Huang, Y., Yaple, Z., \& Yu, R. (2020). Goal-oriented and habitual decisions: Neural signatures of model-based and model-free learning. NeuroImage, 215, 116834. https://doi.org/10.1016/j. neuroimage. 2020.116834

Hui, E., \& Tsang, S. (2012). Self-determination as a psychological and positive youth development construct. The Scientific World Journal, 4, 1-7.

Kitsantas, A., Zimmerman, B. J., \& Cleary, T. (2000). The role of observation and emulation in the development of athletic self-regulation. Journal of Educational Psychology, 92(4), 811-817.

Legault, L., \& Inzlicht, M. (2013). Self-determination, self-regulation, and the brain: Autonomy improves performance by enhancing neuroaffective responsiveness to self-regulation failure. Journal of Personality and Social Psychology, 105(1), 123-138.

Manganelli, S., Cavicchiolo, E., Mallia, L., Biasi, V., Lucidi, F., \& Alivernini, F. (2019). The interplay between self-determined motivation, self-regulated cognitive strategies, and prior achievement in predicting academic performance. An International Journal of Experimental Educational Psychology, 39(4), 470-488.

Markett, S., Wudarczyk, O., Biswal, B., Jawinski, P., \& Montag, C. (2018). Affective network neuroscience. Frontiers in Neuroscience, 12, Article 895. https://doi.org/10.3389/ fnins.2018.00895

Matsushita, K. (2018). An invitation to deep active learning. In K. Matsushita (Ed.), Deep active learning: Toward greater depth in university education (pp. 15-33). Springer.

Mattar, M., \& Bassett, D. (2020). Brain network architecture: Implications for human learning. In M. S. Vitevitch (Ed.), Network science in cognitive psychology (pp. 30-44). Routledge.

McClaskey, K. (2016). Developing the expert learner through the stages of personalized learning. Retrieved March 12, 2021, from: https://udl-irn.org/wp-content/uploads/2018/04/McClaskey_ K2016PersonalizedLearning.pdf

McDowell, M. (2019). Developing expert learners: A roadmap for growing confident and competent students. Corwin.

Meyer, A., \& Rose, D. (2000). Universal design for individual differences. Educational Leadership, 58(3), 39-43.

Meyer, A., Rose, D., \& Gordon, D. (2014). Universal design for learning: Theory and practice. CAST Professional Publishing.

Mithaug, D. E., Mithaug, D. K., Agran, M., Martin, J., \& Wehmeyer, M. (2003). Self-determination learning theory: Construction, verification, and evaluation. Lawrence Erlbaum Publishers.

Opertti, R., Walker, Z., \& Zhang, Y. (2014). Inclusive education: From targeting groups and schools to achieving quality education as the core of EFA. In L. Florian (Ed.), The SAGE handbook of special education (pp. 149-169). SAGE. 
Panadero, E. (2017). A review of self-regulated learning: Six models and four directions for research. Frontiers in Psychology, 8, Article 422.

Perkins, D. (2014). Future wise: Educating our children for changing world. Jossey-Bass.

Perry, N. E., \& Rahim, A. (2011). Studying self-regulated learning in classrooms. In B. Zimmerman $\&$ D. Schunk (Eds.), Handbook of self-regulation of learning and performance (pp. 122-136). Routledge/Taylor \& Francis Group.

Persky, A., \& Robinson, J. (2017). Moving from novice to expertise and its implications for instruction. American Journal of Pharmaceutical Education, 81(9), Article 6065. https://doi. org/10.5688/ajpe6065

Petersen, S., \& Sporns, O. (2015). Brain networks and cognitive architectures. Neuron, 88(1), 207-219.

Piaget, J. (1973). To understand is to invent: The future of education. Grossman Publishers.

Pintrich, P. (2000). The role of goal orientation in self-regulated learning. In M. Boekaerts, P. R. Pintrich, \& M. Zeidner (Eds.), Handbook of self-regulation (pp. 451-502). Academic.

Posner, M., Rothbart, M., Rueda, M., \& Tang, Y.-Y. (2010). Training effortless attention. In B. Bruya (Ed.), Effortless attention: A new perspective in the cognitive science of attention and action (pp. 409-424). Massachusetts Institute of Technology.

Quent, J., Henson, R., \& Greve, A. (2021). A predictive account of how novelty influences declarative memory. Neurobiology of Learning and Memory, 179, 107382. https://doi.org/10.1016/j. nlm.2021.107382

Quirke, M., \& McCarthy, P. (2020). A conceptual framework of Universal Design for Learning (UDL) for the Irish further education and training sector. Retrieved April 17, 2021, from: https://www.solas.ie/f/70398/x/948bcabcc4/udl-for-fet-framework.pdf

Rahman, S., Mahmud, Z., Yassin, S., Amir, R., \& Ilias, K. (2010). The development of expert learners in the classroom. Contemporary Issues in Education Research, 3(6), 1-8.

Raley, S., Shogren, K., \& McDonald, A. (2018). How to implement the self-determined learning model of instruction in inclusive general education classrooms. Teaching Exceptional Children, 51(1), 62-71.

Raley, S., Shogren, K., Rifenbark, G., Thomas, K., McDonald, A., \& Burke, K. (2020). Enhancing secondary students' goal attainment and self-determination in general education mathematics classes using the self-determined learning model of instruction. Advances in Neurodevelopmental Disorders, 4, 155-167.

Ramberg, J., \& Watkins, A. (2020). Exploring inclusive education across Europe: Some insights from the European agency statistics on inclusive education. Forum for International Research in Education, 6(1), 85-101.

Rao, K., Rao, M., \& Ramesh, B. (2016). Predicting learning behavior of students using classification techniques. International Journal of Computer Aplication, 139(7), 15-19.

Reeve, J. (2002). Self-determination theory applied to educational settings. In E. L. Deci \& R. M. Ryan (Eds.), Handbook of self-determination research (pp. 183-203). University of Rochester Press.

Rose, D., \& Meyer, A. (2002). Teaching every student in the digital age: Universal design for learning. ASCD.

Rose, D., \& Strangman, N. (2007). Universal design for learning: Meeting the challenge of individual learning differences through a neurocognitive perspective. Universal Access in the Information Society, 5, 381-391.

Rose, D., Robinson, K., Hall, T., Coyne, P., Jackson, R., Stahl, W., \& Wilcauskas, S. (2018). Accurate and informative for all: Universal design for learning (UDL) and the future of assessment. In S. Elliott, R. Kettler, P. Beddow, \& A. Kurz (Eds.), Handbook of accessible instruction and testing practices: Issues, innovations, and applications (pp. 167-180). Springer International Publishing.

Ryan, R., \& Deci, E. (2000). Self-determination theory and the facilitation of intrinsic motivation, social development, and well-being. American Psychologist, 55(1), 68-78.

Ryan, R., \& Deci, E. (2016). Facilitating and hindering motivation, learning, and well-being in schools: Research and observations from self-determination theory. In K. Wentzel \& D. Miele (Eds.), Handbook of motivation at school (pp. 96-119). Routledge. 
Ryan, R., \& Deci, E. (2017). Self-determination theory: Basic psychological needs in motivation, development, and wellness. Guilford Press.

Ryan, R., \& Deci, E. (2019). Brick by brick: The origins, development, and future of selfdetermination theory. In A. J. Elliot (Ed.), Advances in Motivation Science (pp. 111-156). Elsevier.

Ryan, R., \& Deci, E. (2020). Intrinsic and extrinsic motivation from a self-determination theory perspective: Definitions, theory, practices, and future directions. Contemporary Educational Psychology, 61, 101860.

Schunk, D., \& Zimmerman, B. (1997). Social origins of self-regulatory competence. Educational Psychologist, 32, 195-208.

Schunk, D., \& Zimmerman, B. (1998). Conclusions and future directions for academic interventions. In D. Schunk \& B. Zimmerman (Eds.), Self-regulated learning: From teaching to selfreflective practice (pp. 236-241). Guilford Publications.

Schwartz, M., \& Manning, P. (2018a). Expert learning for law students. Carolina Academic Press.

Schwartz, M., \& Manning, P. (2018b). Expert learning for law students. Carolina Academic Press.

Sharma, U., Armstrong, A. C., Merumeru, L., Simi, J., \& Yared, H. (2019). Addressing barriers to implementing inclusive education in the Pacific. International Journal of Inclusive Education, 23(1), 65-78.

Shogren, K. (2020). Self-determination, preference, and choice. In R. Stancliffe, M. Wehmeyer, K. Shogren, \& B. Abery (Eds.), Choice, preference, and disability: Promoting self-determination across the lifespan (pp. 27-43). Springer International Publishing.

Shogren, K., \& Ward, M. (2018). Promoting and enhancing self-determination to improve the postschool outcomes of people with disabilities. Journal of Vocational Rehabilitation, 48, 187-196.

Shogren, K., Wehmeyer, M., Burke, K., \& Palmer, S. (2017). The self-determination learning model of instruction. Kansas University Centre on Developmental Disabilities.

Shogren, K., Wehmeyer, M., Palmer, S., Rifenbark, G., \& Little, T. (2015). Relationships between self-determination and postschool outcomes for youth with disabilities. The Journal of Special Education, 48(4), 256-267.

Siew, C. (2020). Applications of network science to education. Research: Quantifying knowledge and the development of expertise through network analysis. Education Sciences, 10. https:// doi.org/10.3390/educsci10040101

Siew, C., Wulff, D., Beckage, N., \& Kenett, Y. (2019). Cognitive network science: A review of research on cognition through the lens of network representations, processes, and dynamics. Hindawi. Complexity, Article 2108423. https://doi.org/10.1155/2019/210842

Steiner, H. (2016). The strategy project: Promoting self-regulated learning through an authentic assignment. International Journal of Teaching and Learning in Higher Education, 28(2), 271-282.

Sternberg, R. (2003). What is an "expert student?". Educational Researcher, 32(8), 5-9.

Stobart, G. (2014). The expert learner: Challenging the myth of ability. Open University Press.

Tobin, T., \& Behling, K. (2018). Reach everyone, teach everyone: Universal design for learning in higher education. West Virginia University Press.

Triling, B. (2015). Road maps to deeper learning. In J. Belanca (Ed.), Deeper learning: Beyond 21st century skills (pp. 177-206). Solution Tree Press.

UNESCO. (2015). The education 2030: Incheon declaration and framework for action for the implementation of sustainable development goal 4: Ensure inclusive and equitable quality education and promote lifelong learning opportunities for all. UNESCO. Retrieved November 28, 2020, from https://unesdoc.unesco.org/ark:/48223/pf0000245656

Vygotsky, L. S. (1978). Mind and society: The development of higher mental processes. Harvard University Press.

Walker, J., \& Russell, V. (2019). UDL and executive functioning: Unlocking the capacity for learning. In W. Murawski \& K. Scott (Eds.), What really works with universal design for learning (pp. 97-110). Corwin.

Wardle, S., \& Baker, C. (2020). Recent advances in understanding object recognition in the human brain: Deep neural networks, temporal dynamics, and context. F1000Research, 9, 590. https:// doi.org/10.12688/f1000research.22296 
Wehmeyer, M. (1996). Self-determination as an educational outcome: Why is it important to children, youth, and adults with disabilities? In D. Sands \& M. Wehmeyer (Eds.), Self-determination across the life span: Independence and choice for people with disabilities (pp. 17-36). Paul H. Brookes Publishing Co.

Wehmeyer, M. (1999). A functional model of self-determination: Describing development and implementing instruction. Focus on Autism and Other Developmental Disabilities, 14(1), 53-61.

Wehmeyer, M. (2019). Strengths-based approaches to educating all learners with disabilities. Teachers College Press.

Wehmeyer, M., \& Zhao, Y. (2020). Teaching students to become self-determined learners. ASCD.

Wehmeyer, M., Agran, M., Hughes, C., Martin, J., Mithaug, D., \& Palmer, S. (2007). What works for special-needs learners: Promoting self-determination in students with developmental disabilities. Guilford Press.

Wehmeyer, M., Palmer, S., Agran, M., Mithaug, D., \& Martin, J. (2000). Promoting causal agency: The self-determined learning model of instruction. Exceptional Children, 66(4), 439-453.

Wehmeyer, M., Palmer, S., Shogren, K., Williams-Diehm, K., \& Soukup, J. (2013). Establishing a causal relationship between interventions to promote self-determination and enhanced student self-determination. Journal of Special Education, 46(4), 195-210.

Wehmeyer, M., Shogren, K., Little, T., \& Lopez, S. (2017). Introduction to the self-determination construct. In M. Wehmeyer, K. Shogren, T. Little, \& S. Lopez (Eds.), Development of selfdetermination through the life-course (pp. 3-16). Springer.

Weinstein, C., \& Van Mater Stone, G. (1993). Broadening our conception of general education: The self-regulated learners. New Directions for Community Colleges, 81, 31-39.

Wild, M., \& Heck, J. (2011). Expert learners. Retrieved September 23, 2020, from: https://www. expertlearners.com/el_intro.php

Williams, A., Fawvera, B., \& Hodges, N. (2017). Using the 'expert performance approach' as a framework for improving understanding of expert learning. Frontline Learning Research, 5(3), 64-79.

Woolfolk, A. (2008). Educational psychology. Pearson.

Zeidner, M. (2019). Self-regulated learning: Current fissures, challenges, and directions for future research. High Ability Studies, 30(1-2), 255-276.

Zimmerman, B. (1986). Becoming a self-regulated learner: Which are the key subprocesses? Contemporary Educational Psychology, 11, 307-313.

Zimmerman, B. (1990). Self-regulated learning and academic achievement: An overview. Educational Psychologist, 25(1), 3-17.

Zimmerman, B. (2000). Attaining self-regulation: A social cognitive perspective. In M. Boekaerts, P. Pintrich, \& M. Zeidner (Eds.), Handbook of self-regulation (pp. 13-39). Academic.

Zimmerman, B. (2001). Theories of self-regulated learning and academic achievement: An overview and analysis. In B. J. Zimmerman \& D. H. Schunk (Eds.), Self-regulated learning and academic achievement: Theoretical perspectives (pp. 1-37). Lawrence Erlbaum Associates Publishers.

Zimmerman, B. (2002). Becoming a self-regulated learner: An overview. Theory Into Practice, 41(2), 64-70.

Zimmerman, B. (2015). Self-regulated learning: Theories, measures, and outcomes. In J. Wright (Ed.), International encyclopedia of the social \& behavioral sciences (pp. 541-546). Elsevier.

Zimmerman, B., \& Kitsantas, A. (2005). The hidden dimension of personal competence: Selfregulated learning and practice. In A. J. Elliot \& C. S. Dweck (Eds.), Handbook of competence and motivation (pp. 509-526). Guilford Publications.

Zimmerman, B., \& Schunk, D. (2008). Motivation: An essential dimension of self-regulated learning. In D. Schunk \& B. Zimmerman (Eds.), Motivation and self-regulated learning: Theory, research, and applications (pp. 1-30). Lawrence Erlbaum Associates Publishers. 
Open Access This chapter is licensed under the terms of the Creative Commons Attribution 4.0 International License (http://creativecommons.org/licenses/by/4.0/), which permits use, sharing, adaptation, distribution and reproduction in any medium or format, as long as you give appropriate credit to the original author(s) and the source, provide a link to the Creative Commons license and indicate if changes were made.

The images or other third party material in this chapter are included in the chapter's Creative Commons license, unless indicated otherwise in a credit line to the material. If material is not included in the chapter's Creative Commons license and your intended use is not permitted by statutory regulation or exceeds the permitted use, you will need to obtain permission directly from the copyright holder. 